\title{
Staff Perspectives of the Four-Day School Week: A New Analysis of Compressed School Schedules
}

\author{
Jon Scott Turner ${ }^{1}$, Kim Finch ${ }^{1}$, Uribe-Zarian Ximena ${ }^{1}$ \\ ${ }^{1}$ Department of Counseling, Leadership and Special Education, Missouri State University, Springfield, Missouri, USA \\ Correspondence: Jon Turner, Department of Counseling, Leadership, and Special Education, Missouri State University, \\ Springfield, Missouri, USA.
}

Received: November 6, 2017

Accepted: December 6, 2017 Online Published: December 21, 2017

doi:10.11114/jets.v6i1.2769

URL: https://doi.org/10.11114/jets.v6i1.2769

\begin{abstract}
The four-day school week is a concept that has been utilized in rural schools for decades to respond to budgetary shortfalls. There has been little peer-reviewed research on the four-day school week that has focused on the perception of staff that work in school districts that have recently switched to the four-day model. This study collects data from 136 faculty and staff members in three rural Missouri school districts that have transitioned to the four-day school week within the last year. Quantitative statistical analysis identifies strong support of the four-day school week model from both certified educational staff and classified support staff perspectives. All staff responded that the calendar change had improved staff morale, and certified staff responded that the four-day week had a positive impact on what is taught in classrooms and had increased academic quality. Qualitative analysis identifies staff suggestions for schools implementing the four-day school week including the importance of community outreach prior to implementation. No significant differences were identified between certified and classified staff perspectives. Strong staff support for the four-day school week was identified in all demographic areas investigated. Findings support conclusions made in research in business and government sectors that identify strong employee support of a compressed workweek across all work categories.
\end{abstract}

Keywords: four-day, school week, school calendar, compressed work week

\section{Introduction}

The concept of a compressed work week or 4 day-40 hour work schedule is common in some areas of business and government; working fewer days with longer work hours has been studied for many years in business and administrative research (Cunningham, 1982; Facer \& Wadsworth, 2010; Hodge \& Tellier, 1975). Some employers from the business and public sector have explored options in flexible work schedules for employees to increase productivity, job satisfaction, and employee recruitment while potentially reducing absenteeism and employee turnover (Baltes, Briggs, Huff, Wright \& Neuman, 1999; Wheeler, Gurman \& Tarnowieski, 1972). Law enforcement (Cunningham, 1982), medical careers (Fottler, 1977), and careers in government (Facer \& Wadsworth, 2010) often see work schedules altered to reduce the number of work days by increasing the number of hours worked each day. United States federal law also allows federal agencies to institute compressed work schedules for federal employees (Flexible and Compressed Work Schedules, 1982).

A study by Facer and Wadsworth (2010) found over 55 percent of cities with populations of over 25,000, reported having some type of alternative work schedule for their employees. More and more, school districts in the United States are now looking to alternative school schedules that are very similar to these compressed work week schedules from the business and government world in order to meet challenges in their schools.

In the United States, the general trend regarding school year length has been to increase the number of school days required during a school year or to replace the school days-per-year requirement with an hours-per-year requirement (DeNisco, 2013; Woods, 2015). The option to move to a school calendar based on hours-per-year opened alternatives for schools to reduce the number of school days on the calendar. In 2011, a survey completed by the Washington Post found at least 292 school districts nationwide use the four-day school week, more than double the number estimated two years earlier (Layton, 2011). Most of the existing research on the four-day school week has been conducted by state departments of education or local school districts. "Though over 100 districts across the country operate on a four-day 
week, there is a lack of peer-reviewed research on the topic" (Plucker, Cierniak, \& Chamberlin, 2012, p. 5). While compressed work weeks have been extensively studied within the corporate world, research from the school based settings is sparse.

\subsection{Four-Day School Week: A Cost-Saving Initiative}

The move to a four-day school week is often driven by the need to save money during state or school district budget constraints (Anderson \& Walker, 2015; Bitton, 2016; Cummings, 2015; Donis \& Silvernail, 2009; Henton, 2015; Herring, 2010; Juneau, 2011; Plucker, Cierniak, \& Chamberlin, 2012; Sagness \& Salzman, 1993; Tobias, 2016).

In the case of schools, the four-day school week concept is hardly new in the United States; a shortened school week was used during the Great Depression of the 1930's in hard-hit communities (Donis \& Silvernail, 2009). In the 1970's, the United States gained a renewed interest in reducing the number of school days because of increased heating and transportation costs during the 1973 Arab oil embargo (Cummings, 2015). In 2009, while facing a budget crisis, Hawaii officials implemented seventeen mandatory "Furlough Fridays" for state public schools, implementing a temporary four-day school week statewide (Herring, 2010). The cost-saving efforts extended into other areas of government employment. In 2008, Utah Governor Jon Huntsman announced that his state would implement a mandatory four-day work week for most state workers. At the time of the announcement, Huntsman said the shift in schedule would allow the state to deal with rising energy costs, improving the state's poor air quality, improving services provided to citizens, and recruiting and retaining employees (Facer \& Wadsworth, 2010).

While cost savings is often given as at least one justification for schools moving to the four-day school week, a study completed by the nonpartisan Education Commission of the States determined the maximum financial savings experienced by school districts around the country implementing the four-day school week was just over five percent (Griffith, 2011). Savings have typically been less in a school district's budget making the switch to a shortened school week (Rosenberg, 2015). Other governmental implementations of the compressed work week have also underperformed expectations. Following Utah's statewide implementation in 2008, state officials initially hoped to save \$3 million in energy costs per year; however, the state reduced energy spending by only $\$ 502,000$ during the first year of implementation and much of that savings was attributed to decisions other than the condensed work week. Savings were initially reported in Utah state worker overtime; however, deeper investigation found that most of the reduced overtime cost came from state agencies that were not using the shortened work week (Osterstock, 2010).

Within the school context, some research findings point to public opposition to the four-day school week to save money (Ray, 2003); however, new reasons beyond money savings are now given by school leaders for a shift to longer but fewer school days in American schools (Dam, 2006; DenOuden, 2016). The new generation of school leaders considering a switch to the four-day school week often cite the need for additional staff professional development and collaboration time and the potential for using the shortened week as a tool to recruit and retain high quality staff as reasons for moving to a condensed school week.

\subsection{Four-Day School Week Primarily Foucsed in Small, Rural, and Isolated Schools}

Nationally, the move toward four-day school weeks has been driven mainly in small, rural, and isolated school districts (Richert, 2016). The mountain west states have seen a proliferation of four-day school districts. For example, in Idaho over $9 \%$ of the student population attend schools with four-day weeks (Richert, 2016), and 42 of Idaho's 115 public school districts now follow a four-day a week school calendar (Cummings, 2015). In Colorado, over one-third of the state's public school districts follow a four-day school week; however, only about 3 percent of Colorado's students attend four-day school week schools demonstrating the rural and sparsely populated nature of the school districts (Lefly \& Penn, 2011).

While extremely isolated school districts, often in the Mountain West, have traditionally been the most likely to implement a four-day week, a new wave of less isolated rural districts around the country are now exploring the option. Rural school districts in many states have struggled to keep and attract teachers (Ayala, 2017; Leal, 2017; Missouri Department of Elementary and Secondary Education, 2015). While historically cost savings have primarily been given as the driving factor in the move toward four-day school weeks, more and more the ability to attract teachers (Cooley, 2017; DeNisco, 2014; Hinton, 2017; Stotts, 2017) and to provide additional time for professional development (Morones, 2013) are given by school leaders as the reason for the change.

\subsection{Four-Day School Week in Missouri: A New State Looks at the Model}

In 2009, the state of Missouri enacted legislation giving school districts an option of retaining a five-day school week with a minimum of 174 days or transitioning to a four-day school week with a minimum of 142 days and a minimum of 1044 hours of instruction (Missouri Department of Elementary and Secondary Education, 2015; Rowland, 2014, School Operations, 2009). This change gave Missouri school districts the flexibility to choose the school day calendar that best fit the local context. Since the 2010-2011 school year, 20 of Missouri's 518 public school districts have implemented the 
four-day school week (Missouri Department of Elementary and Secondary Education, 2016) with only one school district returning to the traditional five-day school week (Levin, 2016). The one school district that did return to the traditional five-day school week cited the increase in school day length and the perceived negative impact longer instructional days had on elementary grade children (Newman, Pavolva, \& Luna, 2016).

\subsection{The Educator Perspective}

The four-day work week quickly gained popularity in the business world in the 1970's and 80's only to quickly fade as research reported mixed results and unexpected implementation challenges followed alternative work schedule implementation (Bird, 2010). Workers are now seeking greater opportunities to be with family and friends outside the workplace. From research that focused on alternative work schedules in governmental agencies, the most commonly cited reasons for the alternative work schedules were to improve employee morale, support employee work/life balance, increase productivity, reduce cost, decrease absenteeism, and attract talented employees (Facer \& Wadsworth, 2010). From research conducted in the business and government employment sectors about the 4 day- 40 hour work model, there are many findings that employees, no matter their job classification, are substantially more satisfied with their jobs after a conversion to a four-day work week (Facer \& Wadsworth, 2010; Hodge \& Teller, 1975). Facer and Wadsworth found in their research of a Utah community that shifted their employees to a four day a week ten hours a day work model that nearly 80 percent of employees had a positive experience with the change and nearly two-thirds reported they were more productive at their jobs.

While research has consistently found employees are very supportive of a four-day work week, in the school setting there is some concern that there are "winners and losers" with the implementation of a four-day school week. Certified instructional staff typically do not experience a change in their compensation following the shift to the four-day school week; however, hourly classified staff often do experience reduced compensation.

\subsection{Research Questions}

- Do certified school staff (that generally do not see a change to their salary) support a four-day school week more than classified school staff that typically are paid hourly and may see less income under the model?

- Do school staff that have students currently enrolled in school have a different perspective of the four-day school week model as compared to those without children in school?

- What recommendations for the implementation of the four-day school week do staff have for schools considering a condensed week in the future?

\section{Method}

\subsection{Participants}

Data collection for this study was completed during the 2015-2016 school year. Three independent Missouri public school districts participated in the study; all were within their first year of usage of a four-day school week model. The three rural school districts are located within sixty miles of each other, in two neighboring counties. All school district staff members at these three school districts received questionnaires as part of this study. A total of 324 questionnaires were distributed; 136 questionnaires were completed and returned to the researchers (41.97\% response rate).

\subsection{Procedure}

Survey administration was conducted by the principal investigator in cooperation with the three participating school districts. The school district distributed the survey to all staff members either by email (with a link to an electronic survey) or in paper form; participants were allowed to choose which form they preferred to use. Postage paid return envelopes were provided with paper surveys, which were mailed by the participant directly to the investigator. Schools used automated phone calling systems and school email messages to encourage staff members to complete the survey and return it to the principal investigator. Once the surveys were received, the data were entered into a database for analysis.

\subsection{Instrument}

The 17-item survey instrument was developed based on the review of four-day week literature, contributing to the face validity of the questionnaire. The questionnaire was reviewed by the cooperating school districts' administrators, and their feedback was used to refine the wording and structure of the survey. The four-day school week staff perception survey included demographic information such as: type of employee and number of children enrolled in the school district. The 13 items about staff perceptions had a four-point Likert-type scale and measured the extent of the respondents' agreement with the statements. Items were grouped in two sets: impact and preferences. Impact items referred to the impact the change in school week structure had on school practices and the community. The preferences section included questions about potential drawbacks (i.e., childcare and safety) of the four-day week model and the staff's preference to work under this model. Finally, the last two items provided respondents with an opportunity to express other comments or suggestions they might have about the four-day school week model. 


\subsection{Data Analysis}

For the close-ended items in the questionnaire, SPSS 23 was used for data entry and analysis. First, descriptive statistics were examined for all the responses. Values were assigned to the responses in the questionnaire from -2 (for Strongly Disagree) to +2 (for Strongly Agree). Positive numbers indicate agreement. Then, perception differences among type of staff and employees with or without children were compared using independent $t$-tests; the significance value was set at .05 .

The data from the open-ended questions were downloaded and then analyzed using a combination of deductive categories drawn from the literature and inductive coding to identify emergent themes. NVivo software was used to process the data. Open-ended questions' responses offered insights or issues not captured in the closed questions. The patterns and trends emerging from the data are reported in the next section.

\section{Results}

A total of 136 school staff members from the three school district responded to the four-day school week perception survey. Seventy percent of the staff members reported being a certified employee, with $30 \%$ of respondents self-identifying themselves as classified employees. Certified employees serve a school district in a position that requires an educator certificate issued by the state department of education; typically these employees (which include teachers, administrators, counselors, and librarians) are serving in salaried positions that are not financially impacted by the switch to a four-day school week. Classified employees serve school districts in positions that do not require an educator certificate; typically these employees (which may include cooks, custodians, nurses, bus drivers, instructional aides, and clerical staff) are paid an hourly wage; the switch to a four-day school week may impact their take home pay. Fifty-seven percent of respondents had no children enrolled in school at the time of the survey.

Nine items in the questionnaire were related to the impact the four-day week model has on schools. Table 1 displays the frequency distribution of the responses. The values of the means reported on the table can vary from -2 to 2 with positive values indicating agreement. Generally, the employees' perception about the four-day week model was very positive. Ninety-one percent of the respondents agreed the four-day school week had improved staff morale in the school district $($ Mean $=1.60) ; 87 \%$ agreed the model had had a positive impact on what is being taught in class $($ Mean $=$ 1.53 ); and $76 \%$ agreed the four-day school week has improved the academic quality of their school district (Mean = 1.21). Half or more agreed the four-day school week had helped students considered "at risk" from dropping out of school (Mean = 0.89); the model has helped students with disabilities (Mean = 0.82); the model had made it possible for more students to participate in extra-curricular activities like sports and clubs (Mean $=0.79$ ). Respondents tended to be more neutral about the four-day school week having improved public opinion of the quality of the school district $(0.38)$ and about the model lessened the workload of teachers (Mean $=-0.10$ ).

Table 1. Frequency of Agreement and Mean of Impact Items ( $\mathrm{n}=136)$

\begin{tabular}{|c|c|c|c|c|c|c|}
\hline Impact Items & $\begin{array}{l}\% \\
\text { Agreed } \\
(2)\end{array}$ & $\begin{array}{l}\text { \% Somewhat } \\
\text { agreed } \\
\text { (1) }\end{array}$ & $\begin{array}{l}\% \\
\text { Neutral } \\
(0)\end{array}$ & $\begin{array}{l}\% \text { Somewhat } \\
\text { disagreed } \\
(-1)\end{array}$ & $\begin{array}{l}\% \\
\text { Disagreed } \\
(-2)\end{array}$ & Mean \\
\hline $\begin{array}{l}\text { 1. The four-day school week has had a positive } \\
\text { impact on what is being taught in class. }\end{array}$ & 70 & 17 & 9 & 3 & 1 & 1.53 \\
\hline $\begin{array}{l}\text { 2. The four-day school week has made it possible for } \\
\text { more students to participate in extra-curricular } \\
\text { activities like sports and clubs. }\end{array}$ & 40 & 14 & 35 & 7 & 4 & 0.79 \\
\hline $\begin{array}{l}\text { 3. The four-day school week has helped students with } \\
\text { disabilities. }\end{array}$ & 36 & 14 & 48 & 1 & 1 & 0.82 \\
\hline $\begin{array}{l}\text { 4. The four-day school week has helped students } \\
\text { considered "at risk" from dropping out of school. }\end{array}$ & 42 & 18 & 32 & 4 & 4 & 0.89 \\
\hline $\begin{array}{l}\text { 7. The four-day school week has improved the } \\
\text { academic quality of our school district. }\end{array}$ & 54 & 22 & 17 & 6 & 1 & 1.21 \\
\hline $\begin{array}{l}\text { 8. The four-day school week has improved staff } \\
\text { morale in our school district. }\end{array}$ & 78 & 13 & 4 & 2 & 3 & 1.60 \\
\hline $\begin{array}{l}\text { 9. The four-day school week has improved public } \\
\text { opinion of the quality of our school district. }\end{array}$ & 18 & 26 & 40 & 10 & 7 & 0.38 \\
\hline $\begin{array}{l}\text { 10. The move to the four-day school week has had a } \\
\text { positive economic impact on this community. }\end{array}$ & 32 & 15 & 48 & 2 & 3 & 0.71 \\
\hline $\begin{array}{l}\text { 11. The four-day school week has lessened the } \\
\text { workload of teachers. }\end{array}$ & 23 & 13 & 18 & 23 & 23 & -0.10 \\
\hline
\end{tabular}

Seven items in the survey were related to the staff inclination to continue operating under the four-day week model in their district (see Table 2). Respondents reacted very positively to these items. The researchers found an almost across-the-board support for the model. For example, 96 percent of the respondents agreed students liked the four-day 
school week better than the five-day school week (Mean $=1.83$ ); 91 percent agreed they preferred to work in a school district with a four-day school week (Mean $=1.71$ ); 89 percent agreed they were as productive or more productive with the four-day school week as they were with the five-day school week. It is worth noticing only 12 percent agreed they were concerned about the safety of our students on the weekday they were out of school (Mean $=1.36$ ).

Table 2. Frequency of Agreement and Mean of Preference Items ( $n=136)$

\begin{tabular}{|c|c|c|c|c|c|c|}
\hline Impact Items & $\begin{array}{l}\% \\
\text { Agreed } \\
(2)\end{array}$ & $\begin{array}{l}\text { \% Somewhat } \\
\text { agreed } \\
\text { (1) }\end{array}$ & $\begin{array}{l}\% \\
\text { Neutral } \\
(0)\end{array}$ & $\begin{array}{l}\% \text { Somewhat } \\
\text { disagreed } \\
(-1)\end{array}$ & $\begin{array}{l}\text { \% } \\
\text { Disagreed } \\
(-2)\end{array}$ & Mean \\
\hline $\begin{array}{l}\text { 5. Our students like the four-day school week } \\
\text { better than the five-day school week we had last } \\
\text { year. }\end{array}$ & 88 & 8 & 3 & 0 & 1 & 1.83 \\
\hline $\begin{array}{l}\text { 6. On Mondays, when we are out of school, I am } \\
\text { concerned about the safety of our students. }\end{array}$ & 1 & 11 & 5 & 15 & 68 & -1.36 \\
\hline $\begin{array}{l}\text { 12. I am as productive or more productive with the } \\
\text { four-day school week as I was with the five-day } \\
\text { school week. }\end{array}$ & 81 & 8 & 4 & 2 & 4 & 1.59 \\
\hline $\begin{array}{l}\text { 13. I prefer to work in a school district with a } \\
\text { four-day school week. }\end{array}$ & 83 & 8 & 7 & 1 & 1 & 1.71 \\
\hline $\begin{array}{l}\text { 14. It would have been best to prepare for an } \\
\text { additional year before moving to a four-day school } \\
\text { week. }\end{array}$ & 4 & 5 & 16 & 14 & 61 & -1.22 \\
\hline $\begin{array}{l}\text { 15. The four-day school week model should be } \\
\text { used again next school year. }\end{array}$ & 88 & 3 & 6 & 1 & 2 & 1.72 \\
\hline
\end{tabular}

Table 3. Descriptive Statistics and Group Comparison by Type of Staff

\begin{tabular}{|c|c|c|c|c|c|c|}
\hline & Type & $\mathrm{n}$ & Mean & $\mathrm{sd}$ & $t$ & $d f$ \\
\hline \multirow{2}{*}{$\begin{array}{l}\text { 1. The four-day school week has had a positive impact on } \\
\text { what is being taught in class. }\end{array}$} & Cert. & 95 & 1.55 & .848 & \multirow[t]{2}{*}{.381} & \multirow[t]{2}{*}{134} \\
\hline & Class. & 41 & 1.49 & .810 & & \\
\hline \multirow{2}{*}{$\begin{array}{l}\text { 2. The four-day school week has made it possible for more } \\
\text { students to participate in extra-curricular activities like } \\
\text { sports and clubs. }\end{array}$} & Cert. & 95 & .78 & 1.103 & \multirow[t]{2}{*}{-.119} & \multirow[t]{2}{*}{134} \\
\hline & Class. & 41 & .80 & 1.289 & & \\
\hline \multirow{2}{*}{$\begin{array}{l}\text { 3. The four-day school week has helped students with } \\
\text { disabilities. }\end{array}$} & Cert. & 95 & .82 & .967 & \multirow[t]{2}{*}{-.044} & \multirow[t]{2}{*}{134} \\
\hline & Class. & 41 & .83 & 1.046 & & \\
\hline \multirow{2}{*}{$\begin{array}{l}\text { 4. The four-day school week has helped students considered } \\
\text { "at risk" from dropping out of school. }\end{array}$} & Cert. & 95 & .91 & 1.131 & \multirow[t]{2}{*}{.255} & \multirow[t]{2}{*}{133} \\
\hline & Class. & 40 & .85 & 1.189 & & \\
\hline \multirow{2}{*}{$\begin{array}{l}\text { 5. Our students like the four-day school week better than the } \\
\text { five-day school week we had last year. }\end{array}$} & Cert. & 95 & 1.83 & .558 & \multirow[t]{2}{*}{.023} & \multirow[t]{2}{*}{134} \\
\hline & Class. & 41 & 1.83 & .495 & & \\
\hline \multirow{2}{*}{$\begin{array}{l}\text { 6. On Mondays, when we are out of school, I am concerned } \\
\text { about the safety of our students. }\end{array}$} & Cert. & 95 & -1.33 & 1.125 & \multirow[t]{2}{*}{.554} & \multirow[t]{2}{*}{134} \\
\hline & Class. & 41 & -1.44 & 1.001 & & \\
\hline \multirow{2}{*}{$\begin{array}{l}\text { 7. The four-day school week has improved the academic } \\
\text { quality of our school district. }\end{array}$} & Cert. & 95 & 1.28 & 1.007 & \multirow[t]{2}{*}{1.264} & \multirow[t]{2}{*}{134} \\
\hline & Class. & 41 & 1.05 & .973 & & \\
\hline \multirow{2}{*}{$\begin{array}{l}\text { 8. The four-day school week has improved staff morale in } \\
\text { our school district }\end{array}$} & Cert. & 95 & 1.60 & .916 & \multirow[t]{2}{*}{-.057} & \multirow[t]{2}{*}{134} \\
\hline & Class. & 41 & 1.61 & .891 & & \\
\hline \multirow{2}{*}{$\begin{array}{l}\text { 9. The four-day school week has improved public opinion of } \\
\text { the quality of our school district. }\end{array}$} & Cert. & 95 & .38 & 1.113 & \multirow[t]{2}{*}{-.055} & \multirow[t]{2}{*}{134} \\
\hline & Class. & 41 & .39 & 1.046 & & \\
\hline \multirow{2}{*}{$\begin{array}{l}\text { 10. The move to the four-day school week has had a positive } \\
\text { economic impact on this community. }\end{array}$} & Cert. & 95 & .71 & 1.061 & \multirow[t]{2}{*}{-.136} & \multirow[t]{2}{*}{134} \\
\hline & Class. & 41 & .73 & 1.001 & & \\
\hline & Cert. & 95 & -.13 & 1.518 & -.367 & 134 \\
\hline teachers. & Class. & 41 & -.02 & 1.405 & & \\
\hline 12. I am as productive or more productive with the four-day & Cert. & 95 & 1.57 & .996 & -.351 & 134 \\
\hline school week as I was with the five-day school week. & Class. & 41 & 1.63 & 1.019 & & \\
\hline 13. I prefer to work in a school district with a four-day & Cert. & 95 & 1.75 & .668 & .980 & 134 \\
\hline school week. & Class. & 41 & 1.61 & .919 & & \\
\hline 14. It would have been best to prepare for an additional year & Cert. & 95 & -1.25 & 1.203 & -.492 & 134 \\
\hline before moving to a four-day school week. & Class. & 41 & -1.15 & 1.038 & & \\
\hline 15. The four-day school week model should be used again & Cert. & 95 & 1.77 & .706 & 1.032 & 134 \\
\hline next school year. & Class. & 41 & 1.61 & 1.046 & & \\
\hline
\end{tabular}

Note: None of the differences was significant. 
Table 4. Descriptive Statistics and Group Comparison by Type of Staff

\begin{tabular}{|c|c|c|c|c|c|c|}
\hline & $\begin{array}{l}\text { Children } \\
\text { enrolled }\end{array}$ & $\mathrm{n}$ & Mean & $\mathrm{sd}$ & $t$ & $d f$ \\
\hline \multirow{2}{*}{$\begin{array}{l}\text { 1. The four-day school week has had a positive impact on } \\
\text { what is being taught in class. }\end{array}$} & No & 78 & 1.53 & .785 & \multirow[t]{2}{*}{-.061} & \multirow[t]{2}{*}{134} \\
\hline & Yes & 58 & 1.53 & .903 & & \\
\hline \multirow{2}{*}{$\begin{array}{l}\text { 2. The four-day school week has made it possible for more } \\
\text { students to participate in extra-curricular activities like } \\
\text { sports and clubs. }\end{array}$} & No & 78 & .87 & 1.144 & \multirow[t]{2}{*}{.994} & \multirow[t]{2}{*}{134} \\
\hline & Yes & 58 & .67 & 1.176 & & \\
\hline \multirow{2}{*}{$\begin{array}{l}\text { 3. The four-day school week has helped students with } \\
\text { disabilities. }\end{array}$} & No & 78 & .86 & .977 & \multirow[t]{2}{*}{.484} & \multirow[t]{2}{*}{134} \\
\hline & Yes & 58 & .78 & 1.009 & & \\
\hline \multirow{2}{*}{$\begin{array}{l}\text { 4. The four-day school week has helped students considered } \\
\text { "at risk" from dropping out of school. }\end{array}$} & No & 77 & .82 & 1.144 & \multirow[t]{2}{*}{-.827} & \multirow[t]{2}{*}{133} \\
\hline & Yes & 58 & .98 & 1.147 & & \\
\hline \multirow{2}{*}{$\begin{array}{l}\text { 5. Our students like the four-day school week better than the } \\
\text { five-day school week we had last year. }\end{array}$} & No & 78 & 1.79 & .519 & \multirow[t]{2}{*}{-.904} & \multirow[t]{2}{*}{134} \\
\hline & Yes & 58 & 1.88 & .564 & & \\
\hline \multirow{2}{*}{$\begin{array}{l}\text { 6. On Mondays, when we are out of school, I am concerned } \\
\text { about the safety of our students. }\end{array}$} & No & 78 & -1.36 & 1.057 & \multirow[t]{2}{*}{.016} & \multirow[t]{2}{*}{134} \\
\hline & Yes & 58 & -1.36 & 1.135 & & \\
\hline \multirow{2}{*}{$\begin{array}{l}\text { 7. The four-day school week has improved the academic } \\
\text { quality of our school district. }\end{array}$} & No & 78 & 1.12 & 1.032 & \multirow[t]{2}{*}{-1.328} & \multirow[t]{2}{*}{134} \\
\hline & Yes & 58 & 1.34 & .947 & & \\
\hline \multirow{2}{*}{$\begin{array}{l}\text { 8. The four-day school week has improved staff morale in } \\
\text { our school district }\end{array}$} & No & 78 & 1.60 & .873 & \multirow{2}{*}{-.006} & \multirow[t]{2}{*}{134} \\
\hline & Yes & 58 & 1.60 & .954 & & \\
\hline \multirow{2}{*}{$\begin{array}{l}\text { 9. The four-day school week has improved public opinion of } \\
\text { the quality of our school district. }\end{array}$} & No & 78 & .53 & 1.016 & \multirow[t]{2}{*}{1.794} & \multirow[t]{2}{*}{134} \\
\hline & Yes & 58 & .19 & 1.162 & & \\
\hline \multirow{2}{*}{$\begin{array}{l}\text { 10. The move to the four-day school week has had a positive } \\
\text { economic impact on this community. }\end{array}$} & No & 78 & .82 & .990 & \multirow[t]{2}{*}{1.401} & \multirow[t]{2}{*}{134} \\
\hline & Yes & 58 & .57 & 1.094 & & \\
\hline 11. The four-day school week has lessened the workload of & No & 78 & -.14 & 1.527 & -.414 & 134 \\
\hline teachers. & Yes & 58 & -.03 & 1.426 & & \\
\hline 12. I am as productive or more productive with the four-day & No & 78 & 1.63 & .955 & .539 & 134 \\
\hline school week as I was with the five-day school week. & Yes & 58 & 1.53 & 1.063 & & \\
\hline 13. I prefer to work in a school district with a four-day & No & 78 & 1.78 & 638 & 1.375 & 134 \\
\hline school week. & Yes & 58 & 1.60 & .877 & & \\
\hline 14. It would have been best to prepare for an additional year & No & 78 & -1.27 & 1.040 & -.569 & 134 \\
\hline before moving to a four-day school week. & Yes & 58 & -1.16 & 1.295 & & \\
\hline 15. The four-day school week model should be used again & No & 78 & 1.78 & .714 & 1.010 & 134 \\
\hline next school year. & Yes & 58 & 1.64 & .950 & & \\
\hline
\end{tabular}

Note: None of the differences was significant.

Comparisons were made with the responses between certified and classified staff members and between staff members with and without children enrolled in the school district to see if their perspectives on the four-day week model varied. There were no statistically significant differences between certified and classified staff. Table 3 and Table 4 display the mean, standard deviation, $t$ scores, and degrees of freedom. There were no statistically significant differences between certified and classified members and between staff members with children enrolled in the school district and staff without children in the district. All comparisons were non-significant.

\subsection{Content Analysis}

Several topics emerged from the content analysis performed on the responses to the open-ended questions of the survey. First, presented are the topics staff members discussed when asked if they had recommendations for a school district considering switching to a four-day school week. A summary of the additional comments from staff members is provided in the last question of the survey.

The most common recommendation staff members offered, both certified and classified, was to switch from a five-day to a four-day school week. Most staff members were very optimistic about the adoption of the four-day week model; some were so optimistic that the suggestion they offered was simply, "Do it!" Even so, other staff members were keener and offered insightful recommendations. The recommendations were classified as follows: planning, research, community, and concerns.

\subsection{Increased Need for Teacher Planning Time}

Teacher planning was one of the most common recommendations certified school staff offered. Planning is a time for teachers to plan for upcoming lessons and reflect on their own practice. By drawing from current knowledge and advancement in the field, teachers are expected to make plans about curriculum and lesson plans. It is such a crucial practice, that staff suggesting planning as an essential element for a smooth transition to a four-day week did not come as a surprise. Many certified respondents recommended paying close attention to the important parts of the curriculum because in many cases they had to trim the lessons. One certified staff member mentioned cutting out "fluff" from 
lessons. Another certified staff member expressed it like this, "Having time to prepare is key, looking at what are essential parts to the curriculum - quality not quantity."

Certified staff also mentioned planning related to the weekday off. One certified staff member said, "The additional full day is wonderful in terms of prep [sic] and collaboration time." Another staff member agreed, "It is really nice to have Monday to prepare for the week." Other respondents offered suggestions about the time scheduled for planning in relation to activities already arranged on the weekday off; for example, "Making sure you have a plan in place for what you expect Monday professional development days to look like, and still providing time for teachers to work independently in their rooms without meetings for paperwork/lesson planning/copying/co-teaching collaboration."

\subsection{Impact on Community}

Taking into consideration the community at-large was a recurrent suggestion from both types of staff members. Apparently, some community members who opposed the move to a four-day school week were outspoken, and that damaged the support from part of the community; for example, this is one of the responses received,

Spend as much time as possible educating the community of why the change

will be beneficial. I think we took for granted that our community would

support this and then tried to play damage control. I believe that our biggest

hurdle is/was a few loud community members that believe teachers are trying to get off easy.

Similarly, someone else expressed a parallel sentiment,

The transition has been fairly smooth for our district. Our superintendent

did his homework, school board members did their homework, the

community members were allowed to express their concerns, and

although you can't make EVERYONE [sic] happy, the majority of

our community was 'on board' with the decision the board made,

because all things were considered. The decision to go to a four-day week

was not made lightly.

Another respondent recognized the value of the community support,

I would recommend that any school considering going to a four-day

school week do research of their community to get feedback. By this,

I mean making sure the community is in favor of the change. Having a

school's community support the decision helps make it successful.

Finally, another staff member offered an insight on the community members who were not in favor of the change,

Most of those that do not support [the change] have incorrect information about the four-day school week. Also, most do not have students in the district. While not all parents with students in the district support a four-day school week, they do not feel it has been detrimental to their child.

\subsection{Need for Research Prior to Implimentation}

The suggestion for districts and schools to "do the research" on the topic of four-day school week was closely related to the community support more than to the operational aspect of the model. For example, one staff member wrote,

Definitely have community meetings, after doing research, to offer information to community members in regards to a four day week. The community will talk before holding information meetings and they will arrive with an opinion before knowing all the facts. Be sure to provide FACTUAL [sic] information at meetings and allow for discussion, question and answer sessions, etc.

However, most of the comments related to research were like this, "Review the research and go for it!"

\subsection{Concerns of School Staff}

Staff members voiced different types of concerns, not many, but there were definitely some concerns. One certified staff member summarized his or her concerns as follows,

I still have the same concerns that I had when we started. I don't know how things are panning out in those areas yet. 1) Are the kids retaining as much learning when there's a three day weekend every week? 2) Are the kids getting into more trouble with more idle time. 3) Are my kids that have no food, getting enough to eat? 4) 
Is it an economic hardship on young families who require daycare? 5) Are hourly staff having more trouble financially because we have gone to a four day school week?

\subsection{Staff Identified Benefits and Concerns of the Four-Day School Week}

In summary, here is the list of the components staff members made in open-ended comments section of the instrument that described issues favoring and components that were identified as determents when implementing a four-day school week.

Benefits:

- The model gives teachers an extra day to work on grades and planning instead of taking away the weekend with family

- The model has enable teachers to take courses for personal and professional development

- Less students and staff are absent during the week

- Longer class periods allow teachers to go more in depth and to answer questions which translate in less homework

- Teachers felt they were more focused on teaching

- Less commute time to work

- Morale of staff and faculty had increased

- The model has facilitated scheduling doctor and counseling appointments to avoid conflicts with school days

- It helps having weekdays when the buildings are empty for maintenance work

- It seems savings occur in the transportation department

Concerns:

- The newly adopted model has put the school system "under a microscope"

- There might be a negative impact on local churches because they have to provide another day of food for each child in food programs.

- People will blame the model for the decline in tests scores

\section{Discussion}

While four-day school weeks are common in some areas of the country, the concept is relatively new within the state of Missouri. The faculty and staff participating in this study are part of school districts that are using the four-day school week calendar, a calendar that is unique in their state. In general, this study has found strong support of the four-day school from faculty and staff at the end of the first year of its use in their school districts. Some staff, however, are significantly less positive on the four-day week calendars impact on the perception of the general public about the shortened school week; this research raises some issues for further exploration by researchers. This study did not find significant staff concerns about the four-day school week related to their child's safety.

This study does confirm findings from the business and government employment sectors that demonstrate strong employee support of a condensed workweek. Ninety- one percent of the participants preferred to work in schools with a four-day work week, a deeper investigation of this issue that would explore staff attrition and recruitment efforts is warranted in future research. This study does confirm that staff overwhelmingly perceive the switch to a four-day school week has improved staff morale, which has been identified in previous research. Future research is warranted to investigate if this morale boost extends beyond the first year of implementation.

Within the local context of these three school districts, at the end of the first year of using the four-day school week model, this research has identified strong employee support for the four-day school week model. In all categories, staff perception of the impact the four-day school week has had on their work and their perception of the school is positive. Eighty-nine percent of staff responded they were as productive or more productive in their work under the shortened work week.

School district leaders will find the most significant findings of this research are the conclusions that both salaried certified staff and hourly classified staff strongly support the move to a four-day week, even though some may have had a negative impact on their paycheck. In addition, school districts investigating the four-day school week model will find interesting the comments of faculty related to the implementation, primarily the importance of professional development prior to the school calendar change and reaching out to the school district community prior to making a decision about shortening the school week. 


\section{References}

Anderson, D. M., \& Walker, M. B. (2015). Does shortening the school week impact student performance? Evidence from the Four-Day school week. Education Finance and Policy, 10(3), 314-349. https://doi.org/10.1162/EDFP_a_00165

Ayala, E. M. (2017, July 3). Texas' rural schools need help attracting teachers, and it's all about the pay . Dallas Morning News. Retrieved from https://www.dallasnews.com/news/education/2017/07/26/texas-rural-schools-need-help-attracting-teachers-pay

Baltes, Briggs, Huff, Wright, \& Neuman. (1999). Flexible and compressed workweek schedules: A meta-analysis of their effects on work-related criteria. Journal of Applied Psychology, 84(4), 496. https://doi.org/10.1037/0021-9010.84.4.496

Bird, R. C. (2010). The four-day work week: Old lessons, new questions. Connecticut Law Review, 42(4), 1059-1080.

Bitton, D. (2016, September 29). Morrison and Glencoe optimistic about four-day school week. Stillwater News Press. Retrieved from http://www.stwnewspress.com/news/morrison-and-glencoe-optimistic-about-four-day-school-week/article_a0b6ac b9-77a8-52e0-bf63-6eec1545022c.html

Cooley, A. (2017, January 2). East Newton considers adopting four-day school week. The Joplin Globe. Retrieved from http://www.joplinglobe.com/news/local_news/east-newton-considers-adopting-four-day-school-week/article_4ad2 697d-696a-53e5-b3a2-62661e6b7e5c.html

Cummings, M. (2015, May 13). Adults love the four-day school week. Is it good for the kids? Retrieved from Slate, http://www.slate.com/blogs/schooled/2015/05/13/the_four_day_school_week_is_it_good_for_the_kids.html

Cunningham, J. B. (1982). Compressed shift schedules: altering the relationship between work and non-work. Public Administration Review, 42(5), 438-447. https://doi.org/10.2307/975646

Dam, A. (2006, July). The 4 Day School Week. Denver, Colorado: Colorado Department of Education.

DeNisco, A. (2013, November). More schools choose a four-day week. District Administrator. Retrieved December 30, 2016, from https://www.districtadministration.com/article/more-schools-choose-four-day-week

DenOuden, C. (2016, January 8). It's a 4-day week at some South Dakota schools. Grand Fork Herald. Retrieved from http://www.grandforksherald.com/news/education/3920131-its-4-day-week-some-south-dakota-schools

Donis-Keller, C., \& Silvernail, D. L. (2009, February). Research Brief: A review of the evidence on the four - day school week. Center for Education Policy, Applied Research and Evaluation, University of Southern Maine. Retrieved

from https://usm.maine.edu/sites/default/files/Center\%20for\%20Education\%20Policy,\%20Applied\%20Research,\%20an d\%20Evaluation/CEPARE\%20Brief\%20on\%20the\%204-day\%20school\%20week\%202.10.pdf

Facer II, R. L., \& Wadsworth, L. L. (2010). Four-day work weeks: Current research and practice. Connecticut Law Review, 42(4), 1031-1046.

Flexible and Compressed Work Schedules, 5 U.S.C. $§ \$ 6122$ (1982).

Fottler, M. D. (1977). Employee acceptance of a four-day workweek. The Academy of Management Journal, 20(4), 656-668. https://doi.org/10.2307/255364

Griffith, M. (2011, May). What savings are produced by moving to a four-day school week? Moving to a shorter school week. Retrieved from http://files.eric.ed.gov/fulltext/ED520160.pdf

Henton, D. M. (2015). The four-day school week. The School Administrator, 72(1), 28-32.

Herring, C. (2010, March). Schools’ new math: The four-day week. The Wall Street Journal. Retrieved March 20, 2015, from http://www.wsj.com/articles/SB10001424052748704869304575104124088312524

Hinton, M. (2017, March 4). Are four-day school weeks the way of the future? Education Week. Retrieved from http://blogs.edweek.org/edweek/time_and_learning/2017/03/are_four-day_school_weeks_the_way_of_the_future. html

Hodge, B., \& Tellier, R. (1975). Employee reactions to the four-day week. California Management Review, 18(1), 25-30. https://doi.org/10.2307/41164622

Juneau, D. (2011, October). Four-Day School Week Report in Montana Public Schools. Helena, Montana: Montana Office of Public Instruction. 
Layton, L. (2011, October 28). In trimming school budgets, more officials turn to a four-day week. Washington Post. Retrieved from https://www.washingtonpost.com/local/education/in-trimming-school-budgets-more-officials-turn-to-a-four-day-w eek/2011/10/26/gIQABsiXQM_story.html?utm_term=.c039967c71a5

Leal, F. (2017, May 4). Outside the limelight, rural schools face challenges in finding, and keeping, teachers. EdSource. Retrieved

from https://edsource.org/2017/outside-the-limelight-rural-schools-face-challenges-in-finding-and-keeping-teachers/579 426

Lefly, D. L., \& Penn, J. (2011, November). A comparison of Colorado school districts operating on Four - Day and Five - Day calendars 2011. Retrieved from

http://www.cde.state.co.us/sites/default/files/documents/research/download/pdf/coloradofourdayandfivedaydistrict s.pdf

Levin, K. (2016, September 4). More districts experimenting with four-day school week. The Joplin Globe. Retrieved from

http://www.joplinglobe.com/news/local_news/more-districts-experimenting-with-four-day-school-week/article_6a dda892-725e-11e6-b182-bfc2430abf9d.html

Missouri Department of Elementary and Secondary Education. (2015). Ensure Equitable Access to Excellent Educators. Jefferson City, MO: Missouri Department of Elementary and Secondary Education. Retrieved from https://dese.mo.gov/sites/default/files/Educator-Equity-Plan-Missouri.pdf

Missouri Department of Elementary and Secondary Education. (2016). Missouri comprehensive data system - district and school information-History of the 4 day week. Retrieved December 26, 2016, from https://mcds.dese.mo.gov/quickfacts/Pages/District-and-School-Information.aspx?RootFolder=\%2Fquickfacts\%2F District\%20and\%20School\%20Information\%2FDistrict\%20Calendar\%20Days\%20and\%20Hours\&FolderCTID=0 x012000CD3942FF0AFCAF409A39B99E60390A4F\&View $=\{$ EA01873E-1FEC-400F-BCCB-41AAADDC3B4F \}

Morones, A. (2013, September 18). Iowa district reimagines the five-day school week. Education Week. Retrieved from http://ew.edweek.org/nxtbooks/epe/ew_09182013/index.php?startid=10\#/10

Newman, Z., Pavolva, U., \& Luna, C. (2016, March 10). Many Missouri school districts cite benefits of four-day weeks. KOMU News. Retrieved from http://www.komu.com/news/many-missouri-school-districts-cite-benefits-of-four-day-weeks

Osterstock, T. (2010). A performance audit of the working 4 Utah initiative(Office of the Legislative Auditor General State of Utah). Salt Lake City, UT: Office of the Legislative Auditor General. Retrieved August, 2017, from https://le.utah.gov/audit/10_10arpt.pdf

Plucker, J. A., Cierniak, K., \& Chamberlin, M. (2012). The four-day school week: Nine years later. Center for Evaluation and Education Policy, 10(6), 1-8.

Ray, J. (2003, September 16). Americans resist idea of four-day school week. Gallup. Retrieved December 30, 2016, from, http://www.gallup.com/poll/9256/americans-resist-idea-fourday-school-week.aspx

Richert, K. (2016, May 10). What do the numbers say about four-day school weeks? Idaho Education News. Retrieved from http://www.edweek.org/ew/articles/2015/12/15/what-do-the-numbers-say-about-four-day.html

Rosenberg, M. (2015, January). What math says about four-day week savings. School Administrator, 72(1), 30-31

Rowland, J. (2014, October). Number of instructional days/hours in the school year. Retrieved from http://www.ecs.org/ec-content/uploads/Number-of-Instructional-Days-Hours-in-a-School-Year_Revised.pdf

Sagness, R. L., \& Salzman, S. A. (1993, October). Evaluation of the four-day school week in Idaho suburban schools. Jackson, WY. Retrieved from http://files.eric.ed.gov/fulltext/ED362995.pdf

School Operations, 171, Four-day school week authorized--calendar to be filed with department, 171.029-171.031, (2009).

Stotts, M. (2017, February 3). MPS considering four-day school week. The Miami News-Record. Retrieved from http://www.miamiok.com/news/20170215/mps-considering-four-day-school-week

Tobias, S. P. (2016, April 19). Southeast Kansas district implements four-day school week. The Wichita Eagle. Retrieved from http://www.kansas.com/news/local/education/article72631157.html 
Wheeler, K. E., Gurman, R., \& Tarnowieski, D. (1972). The four-day workweek. New York: AMA.

Woods, J. R. (2015). Instructional time trends. Retrieved from Education Commission of the States Website: http://www.ecs.org/ec-content/uploads/Instructional-Time-Trends_revised-1.pdf

\section{Copyrights}

Copyright for this article is retained by the author(s), with first publication rights granted to the journal.

This is an open-access article distributed under the terms and conditions of the Creative Commons Attribution license which permits unrestricted use, distribution, and reproduction in any medium, provided the original work is properly cited. 